\title{
Spatio-Temporal Changes in Ecology and Fisheries in a Tropical Large Indian Reservoir: Insights From a Long-Term Data Series For Sustainable Development
}

\section{Pranaya Kumar Parida}

CIFRI: Central Inland Fisheries Research Institute

Lianthuamluaia Lianthuamluaia

CIFRI: Central Inland Fisheries Research Institute

\section{Tania Kayal}

CIFRI: Central Inland Fisheries Research Institute

Basanta Kumar Das ( $\sim$ basantakumard@gmail.com )

Central Inland Fisheries Research Institute https://orcid.org/0000-0002-6629-8992

\section{Uttam Kumar Sarkar}

CIFRI: Central Inland Fisheries Research Institute

\section{Satish Koushlesh}

CIFRI: Central Inland Fisheries Research Institute

\section{Bijay Kumar Behera}

CIFRI: Central Inland Fisheries Research Institute

\section{Research Article}

Keywords: Reservoir, fish diversity, fish production, GIS, conservation, sustainable enhancement

Posted Date: October 1st, 2021

DOl: https://doi.org/10.21203/rs.3.rs-885951/v1

License: (9) (i) This work is licensed under a Creative Commons Attribution 4.0 International License. Read Full License

Version of Record: A version of this preprint was published at Environmental Science and Pollution Research on January 24th, 2022. See the published version at https://doi.org/10.1007/s11356-02118187-7. 


\section{Abstract}

The geographic information systems (GIS) play an important role in all geospatial aspects of assessment, monitoring and management of inland open water resources for strategic development in fisheries sector. In India, reservoir fisheries development is one of the flagship programme and several initiatives have been taken up towards enhancement and sustainable development. The present study investigates spatio-temporal changes in ecology and fisheries in Hirakud reservoir, Odisha build across river Mahanadi which features one of the largest dam in South Asia. The reservoir is mainly utilized for electricity generation, irrigation and offers tremendous scope to support fisheries and livelihood. As per the seasonal variation analysis, water spread area was at the minimum during premonsoon period. Most of the water quality parameters including nitrate, phosphate, BOD and alkalinity were higher in the premonsoon period and overall the parameters were under favourable range for fisheries. The present investigation from the fish landing sites of the reservoir, recorded merely 40 fish species, indicating loss of fish diversity as compared to the historical reports. The IUCN conservation status showed that among the 40 species only one species, Wallago attu is under VU category and 4 species Chitala chitala, Ompok bimaculatus, Ailia colia and Bagarius bagarius are under NT category. The analysis of time series annual fish catch data using ARIMA model forecasted the increasing trend of fish production. The water quality parameters were presented in GIS platform for better understanding of the spatial variations over time. Habitat protection of fish breeding grounds, closed seasons, mesh size regulations, scientific management and community participation are recommended as the measures for conservation of fish diversity and sustainable enhancement of fish production in the reservoir.

\section{Introduction}

India is blessed with vast reservoir resources to the tune of around 3.51 million ha which can play a vital role in enhancing fish production to cater livelihood and nutritional security of many rural communities. The development of the fisheries sector is an important agenda of the Government of India for nutritional security, income and livelihood opportunities for an increasing population (Das and Sarkar 2020). Globally, India is a leading fish producing country, ranked second in inland fish production after China (FAO 2020). The present fish yield from Indian reservoirs is low despite its huge potential and the present average yield is about $110 \mathrm{~kg} / \mathrm{ha} /$ year (Sarkar et al. 2018). The low fish production in reservoirs is mainly due to the agro-climatic variations and the inadequate implementation of scientific management practices. Therefore, in order to achieve the enhanced fish production from the reservoirs in a sustainable manner, systematic studies using recent tools and refined guidelines are required to support policymakers and stakeholders.

Fish communities are dynamic in nature and their assemblage changes with time and space under the influence of available resources and various habitat parameters (Grenouillet et al. 2002; Shukla and Bhat 2018). Therefore, it is important to understand how fish communities and assemblages are structured with varying limno-chemical traits in the reservoir ecosystem (Carol et al. 2006). Systematic research in this regard is a prerequisite for biological monitoring, assessing fish yield, and for the development of the 
management and conservation action plans. The fish assemblage and distribution patterns mainly depend on the macro, microhabitat patterns and enviro-climatological variabilities in the region(Sarkar and Bain 2007; Sarkar et al. 2018). Thus, periodical assessment of habitat, fish diversity and assemblage, the impact of stocking, productivity and potential are vital to quantify and develop scientific stock enhancement strategy for the development of fisheries. However, collections of time scale fisheries data including catch patterns and fisheries resources in terms of the reservoir size, water availability, location and numbers, which are the baseline information for the development of fisheries enhancement strategies, are challenging and reports available are inadequate for making strategic guidelines. The mapping of spatio temporal variations of ecology and fish assemblage and habitat characteristics of the reservoirs in GIS platform will serve as a decision support system for a sustainable enhancement of fish production.

Management of these vast water bodies calls for good governance covering a multiplicity of issues ranging from proper fishing rights, involvement of stake holders, strict regulations and enforcement, active research and appropriate choice of technologies. Notwithstanding the low level of fish yield, there are few reservoirs in the country where good management and involvement of the stake holders has resulted in fast forwarding the yield. A record production level of $122 \mathrm{~kg} / \mathrm{ha}$ in the case of GovindSagar Reservoir (Himachal Pradesh, Area - 16000 ha), and $316 \mathrm{~kg} / \mathrm{ha}$ in the case of Chullar Reservoir (Kerala ) are typical examples of success.

Out of total 3.51 million ha reservoir area, Odisha state is bestowed with a total water spread of 1.97 lakhs ha area in the form of Major (3 nos), Medium (3 nos) and Small or Minor ( 1406 nos) reservoirs which account for country's $8.0 \%$ of the total reservoir area. This total reservoir area also constitutes $90 \%$ of the total inland fisheries resource of the state (6.66 lakh ha). Based on the nutrient status of these reservoirs vis-a-vis scientific technologies available in the country, the production level of $80 \mathrm{~kg} / \mathrm{ha}$ in large, $200 \mathrm{~kg} / \mathrm{ha}$ in medium and $300-1000 \mathrm{~kg} / \mathrm{ha}$ in small reservoirs could be easily achieved by judicious and systematic efforts and adoption of requisite management plan over the next ten to twenty years. For achieving these production levels, the action point agenda is not too long and unaccomplishable. Besides, enactment of law with strongest penal clauses for poachers, offenders and anti social elements with a mechanism of round the clock surveillance security at the strategic points of the reservoirs, it is very essential that due attention is paid to the strengthening of fish farms, weed and stump removal, initiation of Departmental Welfare Schemes and such other measures (as alternative livelihood package), undertaking scientific studies, the revival of Co-operative Societies and reorientation of extension and training programmes of different stakeholders etc. The paradigm of success lies in resolving these standing issues.

The Hirakud reservoir plays a strategic role in the economic and social structure in Eastern India. The present knowledge base on the effectiveness of fingerling stocking in enhancing fish production in large tropical reservoirs is not adequate and impact of ecological characteristics of the reservoirs ecosystem and importance in conserving fish biodiversity and other ecosystem services are not well addressed (Sarkar et al. 2018). The review of the literature indicated that the fish yield in Hirakud reservoir was only 
$6.6 \mathrm{~kg} / \mathrm{ha} /$ year (Sugnnan 1995) which was mainly due to indiscriminate exploitation of brooders \& juveniles of commercially important fishes. Presently many resident species show a declining trend in catches that may lead to a serious problem to the biodiversity of the largest lacustrine ecosystem. This needs scientific analysis based on the data available and proper assessment of different factors affecting the catch. Surveys carried out by the different agencies (Department of Fisheries, Govt. of Odisha and ICAR-CIFT Burla Research Station) are available in some grey literature. However, the systematic analysis of the time scale change in fish production, habitat complexity using GIS tools and synthesis of data have not been reported so far from this important open water resource.Thus, in this paper, GIS platform has been used to visualize the time scale data series to understand the spatial variations in water quality over time, forecast fish production, monitor biodiversity and ecosystem health and suggest strategies for sustainable development of this large reservoir ecosystem.

\section{Materials And Methods}

\section{Study area}

Hirakud reservoir is located in the state of Odisha, Republic of India, spreading over three districts (Sambalpur, Bargarh and Jharsuguda). The reservoir is fed by the river Mahanadi and tributary river lbb. It is one of the large reservoirs ( $>10,000 \mathrm{ha}$ ) having a water spread area of $460.8 \mathrm{~km}^{2}$. The reservoir also has the longest dam constructed in India (Fig. 1). The reservoir area has been divided into six sectors (sector I to $\mathrm{VI}$ ) for fisheries management purpose.

\section{Water quality parameters}

Water samples were collected from 14 sampling sites (Fig. 1) across the reservoir. The analysis of water samples were carried out using the standard method of APHA 2005 (Beutler et al. 2014). Additionally, the data was supplemented for parameters like DO, pH, BOD, phosphate, nitrate, conductivity, water surface temperature during 3 different seasons viz. pre monsoon (February-May), monsoon (June-september) and post monsoon (October-January) from published literature (WISA and CDA 2015).

\section{Fish diversityand fish production trend}

The data on basic features of the water body, details of fingerling stocking, fishing practices, fish production, governance, institutional arrangements, and issues and challenges faced by the stakeholders were documented. The fish seed stocking and production data of this reservoir were collected from the Department of Fisheries, Government of Odisha. District wise as well as major group wise fish production data were also collected.

Fishes were collected from different landing sites of Hirakud reservoir during 2016-2019. The fishes were identified using taxonomic keys provided by (Jayaram 2010). The fishes were assesd for their conservation status based on IUCN Red list, 2021. The major gear used for fish harvest was the gill net. The term fingerling used in this study refers to advance size Indian major carps seed $(>100 \mathrm{~mm}$ total length). The fish seed stocking and production data of this reservoir were collected from the Department 
of Fisheries, Government of Odisha. The average fish yield $(\mathrm{kg} / \mathrm{ha} / \mathrm{yr})$ was calculated by dividing the total annual fish production in $\mathrm{kg}$ by the average area of the reservoir in ha. Observation of other researchers on fish diversity were collected and compared with the present study.

\section{Data analysis and GIS application}

The preliminary analysis was conducted using MS Excel - 2007. The time series data of annual fish production from 1958 to 2018 was used to forecasted the fish production through ARIMA model using auto.arima function of forecast package of $\mathrm{R}$ software (Hyndman and Khandakar 2008). Taxonomic distinctness $\left(\Delta^{*}\right)$ and Sorensen's Index $\left(\mathrm{S}_{\mathrm{s}}\right)$ were used to compare the fish diversity with the other observations made by earlier researchers (Job et al. 1955; Singh 2014) using Vegan package of $R$ software (Oksanen et al. 2020). The water spread area of the reservoir imagery was collected from Landsat-8 data of 2018 from USGS websites for our analysis. The spatial analysis was conducted using Arc GIS- 10.2.1 for water spread area, variation of water quality parameters etc.

\section{Result}

\section{Hydrology}

The total catchment area of Hirakud reservoir is found to be about $83395 \mathrm{~km}^{2}$ and shoreline as $643.6 \mathrm{~km}$ (Fig. 2).The total storage capacity of the reservoir was $6.6 \mathrm{~m} / \mathrm{a} / \mathrm{ft}$ whereas the live storage capacity was $4.72 \mathrm{~m} / \mathrm{a} / \mathrm{ft}$. The maximum depth of the reservoir varied from $179.026 \mathrm{~m}$ (DRL) and $192.017 \mathrm{~m}$ (FRL), respectively.

The reservoir is rain fed and hence $80 \%$ of the runoff occurs during the monsoon months of June to September from its catchment area. More than $65 \%$ of the vast catchment area $\left(83,395 \mathrm{Km}^{2}\right)$, stretching over the Central Indian Plateau is fertile and productive. The average annual rainfall in the region is around $152 \mathrm{cms}$. The reservoir has a high shore line development index of 13.5. The total annual inflow has been estimated as $2.22 \times 10^{4}$ million $\mathrm{m}^{3}$ against an outflow of $2.31 \times 10^{4}$ million $\mathrm{m}^{3}$ (WISA and CDA 2015). The multipurpose use of dam water from the reservoir for different purposes includes irrigation (5.24\%), industrial use (1.56\%), hydropower $(29.77 \%)$, municipal use $(0.02 \%)$ and down stream release (63.04\%), respectively.

The water holding capacity was found to be decreasing year by year. In the year, 2006 the water holding capacity was 5,930.22 MCM, which was reduced to 5,656.43 MCM in the year 2014. The loss in capacity is about $30.24 \%$ (WISA and CDA 2015). The analysis of the seasonal variation of the water spread area indicated that the water area has been reduced by around $10 \%$ from monsoon to pre-monsoon (Fig. 3. a \& b). The seasonal variation of the water spread area of the reservoir in the different districtsare shown in Table 1. 
Table 1

Seasonal variation of water spread area of Hirakudreservoir

\begin{tabular}{|llll|}
\hline & $\begin{array}{l}\text { Monsoon } \\
\text { (Area in ha) }\end{array}$ & $\begin{array}{l}\text { Post- Monsoon } \\
\text { (Area in ha) }\end{array}$ & $\begin{array}{l}\text { Pre-Monsoon } \\
\text { (Area in ha) }\end{array}$ \\
\hline Hirakud & $60,617.70$ & $57,019.50$ & $53,990.43$ \\
\hline Baragarh District & $11,817.00$ & $11,233.98$ & $10,879.00$ \\
\hline Jharsuguda District & $35,455.85$ & $32,858.48$ & $30,938.87$ \\
\hline Sambalpur District & $13,344.84$ & $12,927.03$ & $12,172.54$ \\
\hline
\end{tabular}

\section{Water quality parameters}

The water quality parameters of Hirakud reservoir were shown in Table 2. Water temperature ranged from 25.5 to $32.5^{\circ} \mathrm{C}$ with the highest in premonsoon period. Nutrient parameters like nitrate and phosphate were higher during the premonsoon period. The BOD was higher during pre-monsoon and monsoon periods. The alkalinity and microbial load were higher in the pre-monsoonperiod.The changes in the water quality parameter of the reservoir have been arranged in GIS platform for the year 2008 and 2016. The spatio-temporal changes of few water quality parameters (temperature, conductivity, nitrite, DO, $\mathrm{pH}$ and BOD) during 2008 and 2016 is presented in GIS platform (Fig. 4). Among the studied parameters, temperature, $\mathrm{pH}$ and $\mathrm{DO}$ showed more spatial and temporal variations. 
Table 2

Seasonal variation of water quality parameters of Hirakudreservoir(Source: WISA and CDA, 2015)

\begin{tabular}{|llll|}
\hline Parameters & Pre monsoon & Monsoon & Post monsoon \\
\hline Temperature $\left({ }^{\circ} \mathrm{C}\right)$ & 32.5 & 27.5 & 25.5 \\
\hline Turbidity $(\mathrm{NTU})$ & 11.55 & 485.5 & 16.45 \\
\hline TDS $(\mathrm{mg} / \mathrm{l})$ & 132.5 & 89 & 97.5 \\
\hline TSS $(\mathrm{mg} / \mathrm{l})$ & 76 & 248 & 20.5 \\
\hline pH & 7.6 & 7.7 & 7.6 \\
\hline Conductivity $(\mu \mathrm{S} / \mathrm{cm})$ & 187.5 & 160 & 169 \\
\hline DO $(\mathrm{mg} / \mathrm{l})$ & 7.6 & 7 & 8.7 \\
\hline Chloride $(\mathrm{mg} / \mathrm{l})$ & 7.5 & 6.35 & 9.3 \\
\hline Total alkalinity $(\mathrm{mg} / \mathrm{l})$ & 103 & 44 & 76 \\
\hline COD $(\mathrm{mg} / \mathrm{l})$ & 7.8 & 11.6 & 7.2 \\
\hline BOD $(\mathrm{mg} / \mathrm{l})$ & 1.05 & 1.6 & 0.7 \\
\hline Nitrate $(\mathrm{mg} / \mathrm{l})$ & 1.7 & 0.65 & 0.4 \\
\hline Phosphate $(\mathrm{mg} / \mathrm{l})$ & 0.05 & 0.1 & 0 \\
\hline
\end{tabular}

\section{Fish harvesting devices}

Gill net was the major fishing gear operated in Hirakud Reservoir, the other fishing gear included dragnets, shore seines, cast nets, stake nets, and longlines. Three different types of gill nets were operated within 3 to $10 \mathrm{~m}$ depth. The meshsize of nets varied from $130 \mathrm{~mm}$ to $230 \mathrm{~mm}$ and the use of gill nets below 100 $\mathrm{mm}$ mesh size were prohibited. The destructive shore seine with zero mesh size locally called "Dullungi" is operated illegally inspite of the ban. Locally built plank built boats, canoes (dingi 5.5 to $6 \mathrm{~m}$ size) are used by the fishermen for fishing operations.

\section{Fish production pattern}

The analysis of data indicated that majority of the fish catch was contributed by catfish and total annual catfish landing was more than $50 \%$ of the total fish production (8200 MT) in 2018-19. The major carps and minor carps contributed around $40 \%$ of the total fish catch. The miscellaneous group contributed only $7 \%$ of the total fish landing (Fig. 5).

The fish production trend of reservoir indicated a drastic increase from the year 2010 onwards (Fig. 6) which was considerably low before 2010. Based on the time series data the fish production was forecasted (Fig. 6), which clearly indicated that the fish production is likely to follow upward trend in the forthcoming years. Additionally, it was observed that fish production in Sambalpur district contributed the 
highest catch ( $49 \%$ of the total fish production) followed by Jharsuguda (35\%) and Bargarh (16\%) district (Fig. 7).

\section{Stocking of fingerlings}

During the year 2009-10 HirakudReservoir Development programme was implemented through a scheme under National Fisheries Development Board (NFDB), India through FFDAs includingall 3 districts.Thereafter, the stocking was continued during 2012-13 to 2015-16 (Fig. 8).

Maximum fingerlings were stocked in sector II, followed by sector-I, and sector V (Table 3). Sector IV represented only $11 \%$ to the total seed stocked in the reservoir (Fig. 9). As per the guidelines, in the case of more catfish catches in reservoirs, the stocking density should be around 250 nos./ha/year. However, the fingerling stocking per ha was found to be more in sector $V$ and less in sector IV. In most of the sectors the stocking is less than the recommendation, however in sector $-\mathrm{V}$, it had more than the recommended guidelines.

Table 3

Fingerling stocking in different sectors of the reservoir

\begin{tabular}{|ll|}
\hline Sector & Fingerling stocking per ha per $y \mathbf{r}$ \\
\hline Sector I & 166 \\
\hline Sector II & 158 \\
\hline Sector IV & 69 \\
\hline Sector V & 377 \\
\hline Sector VI & 189 \\
\hline
\end{tabular}

\section{Fish diversity and conservation status}

The present fish diversity of the Hirakud reservoir was attributed to 40 species distributed under 11 order and 16 families (Table 4) indicating considerable decline in biodiversity. The order cypriniformes contributed the highest number of species consisting of 16 species followed by siluriformes of 11 species. Only one species Oreochromis niloticus was found to be exotic in the reservoir. The IUCN conservation status indicated that 34 species were under LC (least concern) category, one species Wallago attu was found to be under VU (vulnerable) category, another one species under DD (data deficient) category and four species Chitala chitala, Ompok bimaculatus, Ailia colia and Bagarius bagarius were under NT (near threatened) category (Fig. 10). The comparative assessment of the fish diversity of Hirakud reservoir indicated that the number of species or the species richness in the present study of 40 species was lower than 86 species observed by Job et al. (1955) and 56 species by Singh (2014) in Hirakud region of Mahanadi river. The highest number of exotic species 5 species were recorded by Singh (2014) followed by the present study of one species, but no exotic species was observed by Job 
et al. (1955). The present study indicated that 2 species (Tor tor and Puntius dorsalis) were distinct or not observed by the others in Hirakud region. 
Table 4

Ichthyofauna diversity of Hirakud reservoir

\begin{tabular}{|c|c|c|c|c|}
\hline & Order & Family & Scientific name & $\begin{array}{l}\text { IUCN conservation } \\
\text { status }\end{array}$ \\
\hline 1 & Cypriniformes & Cyprinidae & Gibelioncatla & LC \\
\hline 2 & & & Labeofimbriatus & LC \\
\hline 3 & & & Labeocalbasu & LC \\
\hline 4 & & & Labeorohita & LC \\
\hline 5 & & & Labeogonius & LC \\
\hline 6 & & & Labeobata & LC \\
\hline 7 & & & Cirrhinusmrigala & LC \\
\hline 8 & & & Cirrhinusreba & LC \\
\hline 9 & & & Tor tor & DD \\
\hline 10 & & & Systomussarana & LC \\
\hline 11 & & & Osteobramacotio & LC \\
\hline 12 & & & Puntius sophore & LC \\
\hline 13 & & & Pethiaticto & LC \\
\hline 14 & & & Puntius chola & LC \\
\hline 15 & & & Puntius dorsalis & LC \\
\hline 16 & & & Salmostomabacaila & LC \\
\hline 17 & Siluriformes & Bagridae & Sperataseenghala & LC \\
\hline 18 & & & Sperataaor & LC \\
\hline 19 & & & Mustusgulio & LC \\
\hline 20 & & & Rita chrysea & LC \\
\hline 21 & & Schilbeidae & Siloniasilondia & LC \\
\hline 22 & & & Eutropiichthysvacha & LC \\
\hline 23 & & Siluridae & Wallago attu & VU \\
\hline 24 & & & Ompokbimaculatus & NT \\
\hline 25 & & Pangasiidae & Pangasiuspangasius & LC \\
\hline 26 & & Sisoridae & Bagariusbagarius & NT \\
\hline
\end{tabular}




\begin{tabular}{|lllll|}
\hline & Order & Family & Scientific name & $\begin{array}{l}\text { IUCN conservation } \\
\text { status }\end{array}$ \\
\hline 27 & & Ailiidae & Ailiacoila & NT \\
\hline 28 & Osteoglossiformes & Notopteridae & Notopterusnotopterus & LC \\
\hline 29 & & Notopteridae & Chitalachitala & NT \\
\hline 30 & Clupeiformes & Clupeidae & Gudusiachapra & LC \\
\hline 31 & Perciformes & Ambassidae & Chanda nama & LC \\
\hline 32 & Anabantiformes & Channidae & Channastriatus & LC \\
\hline 33 & & Channidae & Channamarulius & LC \\
\hline 34 & & Channidae & Channa punctatus & LC \\
\hline 35 & Cichliformes & Cichlidae & Oreochromis niloticus & LC \\
\hline 36 & Gobiiformes & Gobiidae & Glossogobiusgiuris & LC \\
\hline 37 & Mugiliformes & Mugilidae & Rhinomugilcorsula & LC \\
\hline 38 & Beloniformes & Belonidae & Xenetodoncancila & LC \\
\hline 39 & Synbranchiformes & Mastacembelidae & Mastacembelusarmatus & LC \\
\hline 40 & & & Macronathuspancalus & LC \\
\hline
\end{tabular}

Based on Sorensen's Index $\left(\mathrm{S}_{\mathrm{S}}\right)$, the highest overlap of species composition has been observed between the present study and Singh (2014) but the species composition considerably differed between the present study and the recordof Job et al (1955) (Table 5). The present study indicated highest taxonomic distinctness $\left(\Delta^{\star}\right)$ as compared to the other observations made by Singh (2014) and Job et al (1955). Comparatively, the report of Singh (2014) showed more similarity in the taxonomic distinctness with the present study, however, Job et al (1955) showed a distinct taxonomic distinctness pattern as compared to other observations (Fig. 11).

Table 5

Sorensen's Index $\left(\mathrm{S}_{\mathrm{s}}\right)$ matrix of fish in Hirakud

\begin{tabular}{|llll|}
\hline & Job et al (1955) & Singh (2014) & Present \\
\hline Job et al (1955) & 1.0 & & \\
\hline Singh (2014) & 0.59 & 1.0 & \\
Present & 0.57 & 0.62 & 1.0 \\
\hline
\end{tabular}

\section{Discussion}


The hydrobiological parameters have a major role in inland fish production, and they are the key factors for developing management strategies. The ecology and biota in reservoirs are mainly dependent on the habitat characteristics of the resources. The physicochemical characteristics of the water and soil determine the productivity of a reservoir (Montanhini Neto et al. 2017). The analysis of water quality parameters revealed that the reservoirs are conducive for fisheries enhancement. The variation of temperature in the present study follows the seasonal pattern of typical Indian agro-climatic conditions with the highest in summer or the pre-monsoon period. Several authors also observed the same pattern of temperature variations in different reservoirs of India (Narayana et al. 2008; Garg et al. 2009; Verma et al. 2011; Prabhahar et al. 2012). The higher value of nutrients in the pre-monsoon seasons during the present study might be due to evaporation which increases the nutrient content of the water. In accordance with the present findings, many authors also observed the same pattern of seasonal variations of nutrients in reservoirs and lakes (Gorham 1961; Rajashekhar et al. 2007; Vetriselvi et al. 2011; Pawar and Shembekar 2012). BOD which is an important parameter for the assessment of the ecological health of aquatic ecosystem was higher in premonsoon and monsoon periods which is directly related to the availability of water in the reservoir and the accumulation of organic load through the runoff from the catchment during the rainy season. The microbial load is also an important parameter for assessing the water quality parameters. The microbial load was higher in the summer which is due to the enhancement of the growth of the microbes at the higher temperature during pre-monsoon period.

Stock enhancement programs help to augment the existing fish stock and yield from reservoirs (Cowx 1994; De Silva and Funge-Smith 2005; Sarkar et al. 2020). Fisheries enhancement and conservation measures were strictly observed in the reservoir through the introduction of Reservoir Fishery Policy-2003 during the year 2004-05 which increased fish production. Moreover, during the year 2009-10 Reservoir Development programme implemented by National Fisheries Development Board (NFDB), India through FFDAs in three districts of Odisha (Sambalpur, Bargarh \& Jharsuguda) included Hirakud reservoir. During the year 2010-11 \& 11-12, advanced fingerlings were stocked by FFDA, Sambalpur, Bargarh and Jharsuguda under the programme to compensate the loss of juveniles due to indiscriminate fishing. The stocking continued during the year 2012-13 to 2015-16. In the present study a considerable higher fish production during the year 2010-11 to 2015-16, showed the systematic implementation of the fingerling stocking programme by the National Fisheries Development Board, India. The high fish yield may be attributed to high natural productivity (Sugnnan 1995; Das et al. 2008; Sarkar et al. 2018). The enhancement strategy in Indian reservoirs largely depends on indigenous carp species, viz. G. catla, L. rohita, C. mrigala, L. calbasu, L. fimbriatus, and C. cirrhosus besides, the minor carps such as L. bata, Systomus sarana, etc. and catfish species (De Silva and Funge-Smith 2005). In accordance with the present finding, the positive impact of stocking in the different categories of reservoirs is reported in India (Sugunan and Katiha 2004; Sarkar et al. 2020; Lianthuamluaia et al. 2021) and in other parts of the world (Phan and De Silva 2000; Nguyen et al. 2001, 2005; Wijenayake et al. 2005; Amarasinghe and Nguyen 2010; Pushpalatha and Chandrasoma 2010; Pushpalatha et al. 2017). According to Sarkar and Mishal (Sarkar and Mishal 2017), the potential fish yield for a large reservoir is $100 \mathrm{~kg} / \mathrm{ha} / \mathrm{yr}$. The earlier report in Aliyar reservoir stated that the stocking programme impacted the fish catch with an increased yield from 
26.7 to $136 \mathrm{~kg} / \mathrm{ha} / \mathrm{yr}$ (Selvaraj et al. 1990). Through sustainable stocking and fishing management programmes in Suvarnavathy reservoir of Karnataka, the fish yield increased from 116 to $197 \mathrm{~kg} / \mathrm{ha} / \mathrm{yr}$ (Rao et al. 2013). Similar results are also reported in Uttar Pradesh (150 and $140 \mathrm{~kg} / \mathrm{ha} / \mathrm{yr}$ in Gulariya and Bachhra reservoirs), and Rajasthan ( $94 \mathrm{~kg} / \mathrm{ha} / \mathrm{yr}$ in Budha Beratha reservoir) where the fish yield increased as a result of stocking (Sugunan 2011). If the recruitment of new stock and conservation measures are taken up simultaneously and continued for some more years there will be a spectacular increase in fish production of the reservoir. The increasing trend of fish production in the reservoir is well supported by the ARIMA model which also predicted the upward trend in fish production.

In India, staggered information on fish yield potential and habitat data of large reservoirs are available. Consequently, development of an integrated baseline database on ecology, morpho-edaphic factors, climatic parameters, harvest composition, biodiversity and yield potential in GIS platform is essential for calculating the optimum stocking rates and sustainable production from large reservoirs. The present analysis and observation indicate the prospect of enhancing fish yield and production from large reservoirs through stocking enhancement. Indian reservoirs are suitable for fisheries enhancement but they still remain understocked and unscientifically managed to give ample scope for fisheries development by bridging the gap between fish production potential and yield. There are several issues in implementing successful enhancement programmes in large reservoirs. The varying water level is also a challenge in estimating the effective water area for successful stocking program (Sarkar et al. 2018). The use of GIS and remote sensing will help to resolve this issue and thus assist in decision making. Moreover, the use of mobile based apps for fish catch estimation holds great potential in central Indian reservoirs (Karthikeyan et al. 2020).

The stocking was found to be ineffective in some of the large reservoirs. The role of auto stocking in fish yield and identification of breeding grounds are important researchable issues in large reservoirs. The food web based modeling (Behera et al. 2020) can be attempted for optimising the fish yield. The application of Lorenzen model (Lorenzen 2000) also holds great potential in large Indian reservoirs. Fishing is also difficult in many large reservoirs; socustomization of fishing gear and crafts are also essential for efficient exploitation of stocked fish (Sugunan 2011).

There are several challenges in the ecological assessment of large reservoirs. The water level influences productivity and the productivity is in turn, influenced greatly by external random factors. The lack of comprehensive historical data makes it difficult to estimate the temporal changes in ecology (Sarkar et al. 2018). Lack of scientific knowledge base on auto recruitment, migratory patterns and site fidelity of fishes, and complex food web dynamics in large reservoirs is still a challenge (Lianthuamluaia et al. 2019; Sandhya et al. 2019).

Fish play an important component in maintaining the ecological health of the aquatic ecosystem. Conservation of fish diversity needs to be taken into consideration while managing reservoirs or lakes. The present observations of the fish diversity indicated that the number of species has declined. Job et al. (Job et al. 1955) recorded 86 fish species and Singh (Singh 2014)) recorded 56 species from Hirakud 
region, but during the present study, only 40 species were recorded. Habitat alteration is one of the most important factors for the loss of fish diversity (Shrestha 1990; Dehadrai et al. 1994; Sehgal 1994). Many fishes need a particular environment and ecological conditions for breeding, migration and larval development to complete their life cycle. Habitat alteration can greatly hamper the biological process of many fishes to increase their populations. Water flow and water availability are among another important factors influencing fish breeding and growth. Reservoirs are not constructed for fish production, the water use in the form of electric generations, irrigation and flood control play a very important role in the water availability of reservoirs. The fluctuations of water availability in reservoirs due to different water use are among the major causes of reduction in fish species richness. Pollution or deterioration of water qualities can be important factors causing loss of fish diversity (Dehadrai et al. 1994). Due to the increase in human populations and uncontrolled anthropogenic activities our environment including the aquatic environment is deteriorating which has drastically impacted biodiversity including fish. Illegal fishing and overexploitation are also among the main causes for the loss of fish diversity in inland waters (Dehadrai and Ponniah 1997). Climate change impacted fish diversity directly or indirectly. Irregular rainfall patterns greatly impacted water availability and water flow which can greatly influence the breeding biology of fish. An increase in temperature also impact water availability through evaporation which can influence the fish biology of many fishes.

The present study indicated that most of the water quality parameters were in the favorable range for fish and associated flora and fauna. However, the species richness of fish has gone down due to several reasons. The fingerling stocking in medium and large reservoirs was rendered ineffective in India (Sreenivasan 1984). But the findings of the present study reveals that large reservoirs are also suitable for fisheries enhancement.The impact of stocking depends on the habitat quality, management practices, quality of seed, seed stocking ration, species performance and carrying capacity of a water body. The National Fisheries Development Board, India has suggested stocking of an average 1000 fingerlings/ha in Indian reservoirs, however, for sustainable production the management practices depending on the ecology and climatic condition of the water resources are required. The location-specific management practices are essential to achieve the production goals. Based on the present study, observations and discussion with the stakeholders, the following recommendations are suggested:

Fishing ban period /closed season should be practiced in the reservoirs to avoid the catch of brooders. The priority fish habitat suitable for breeding grounds should be identified and protected. Advanced fingerling stocking ( $120 \mathrm{~mm}$ in size) is advocated, which may ensure better survival and yield. The carrying capacity should be estimated to determine the optimum stocking and production. Nursery and rearing facility in suitable shoreline of reservoir along with seed raising in enclosures are recommended. The application of ecological modeling for devising stocking strategy, species selection and the combination would help the managers to utilize the fish production potential. The dynamics of physical, chemical and biological attributes of reservoirs are still not well documented which may be done at the periodical interval to understand the changing pattern in the context of environmental challenges. The management of the reservoir should be done in a participatory mode so that the local fishers should be involved in implementing the regulatory measures for fisheries enhancement and development. A sound 
policy framework on reservoir fisheries for management, governance and institutional arrangement would be important in accomplishing the potential of multi-use reservoir.

\section{Declarations}

\section{Funding}

This research did not receive any specific grant from funding agencies in the public, commercial or notfor- profit sector to carry out.

\section{Authors' contribution:}

BKD and PKP: conceptualization and methodology; Lian, PKP, and TK : data collection and data analysis; PKP, Lian, SK and UKS :Manuscript preparation; BKD and BKB: critical review of the MS

\section{Conflict of interest}

The authors have no conflict of interest.

\section{Data availability and material}

The data set supporting the results of this article are included within article.

\section{Ethics approval}

Not applicable

\section{Consent to participate}

Consent of fishermen and department officials were taken before taking the information about the reservoir and its fisheries.

\section{Consent to Publish}

Not applicable

\section{Acknowledgement}

The authors would like to acknowledge the Director, ICAR-CIFRI to provide opportunity to carry out this research work.

\section{References}

1. Amarasinghe US, Nguyen TTT (2010) Enhancing rural farmer income through fish production: secondary use of water resources in Sri Lanka and elsewhere. In: Success stories in Asian 
aquaculture. Springer, pp 103-130

2. Behera PR, Parida PK, Karna SK et al (2020) Trophic fingerprinting of Chilika, a Ramsar site and the largest lagoon of Asia using Ecopath. Reg Stud Mar Sci 37:101328. https://doi.org/10.1016/j.rsma.2020.101328

3. Beutler M, Wiltshire KH, Meyer B et al (2014) APHA (2005), Standard Methods for the Examination of Water and Wastewater, Washington DC: American Public Health Association. Ahmad SR, Reynolds DM (1999), Monitoring of water quality using fluorescence technique: Prospect of on-line process control,. Dissolved Oxyg Dyn Model Case Study A Subtrop Shallow Lake 217:95

4. Carol J, Benejam L, Alcaraz C et al (2006) The effects of limnological features on fish assemblages of 14 Spanish reservoirs. Ecol Freshw Fish 15:66-77

5. Cowx IG (1994) Stocking strategies. Fish Manag Ecol 1:15-30

6. Das AK, Shrivastava NP, Vass KK, Pandey BL (2008) Management strategies for enhancing fish production in Madhya Pradesh reservoirs. In: Proceedings of Taal 2007: The 12th World Lake Conference. Japan: International Lake Environment Committee Foundation, pp 1295-1300

7. Das BK, Sarkar UK (2020) Inland open water fisheries potential in India. article

8. De Silva S, Funge-Smith S (2005) A review of stock enhancement practices in the inland water fisheries of Asia

9. Dehadrai PV, Das P, Verma S (1994) Threatened Fishes of India

10. Dehadrai PV, Ponniah AG (1997) Conserving India's fish biodiversity. Int J Ecol Environ Sci 23:315326

11. FAO (2020) WORLD FISHERIES AND AQUACULTURE THE STATE OF SUSTAINABILITY IN ACTION. https://doi.org/10.4060/ca9229en

12. Garg RK, Rao RJ, Saksena DN (2009) Water quality and conservation management of Ramsagar reservoir, Datia, Madhya Pradesh. J Environ Biol 30:909

13. Gorham E (1961) The chemical composition of some waters from dune slacks at Sandscale, North Lancashire. J Ecol 79-82

14. Grenouillet G, Pont D, Seip KL (2002) Abundance and species richness as a function of food resources and vegetation structure: juvenile fish assemblages in rivers. Ecography 25:641-650

15. Hyndman RJ, Khandakar Y (2008) Automatic time series forecasting: the forecast package for R. J Stat Softw 27:1-22

16. Jayaram KC (2010) The Freshwater Fishes of the Indian Region (Revised second edition)

17. Job TJ, David A, Das KN (1955) Fish and fisheries of the Mahanadi in relation to the Hirakud Dam. Indian J Fish 2:1-36

18. Karthikeyan M, Malay N, Das BK et al (2020) A modeling approach to determine the harvest potential for sustainable fishery in stocked reservoirs. Int J Ecol Environ Sci 46:241-246

19. Lianthuamluaia L, Mishal P, Panda D et al (2019) Understanding spatial and temporal patterns of fish diversity and assemblage structure vis-a-vis environmental parameters in a tropical Indian 
reservoir. Environ Sci Pollut Res 26:9089-9098

20. Lianthuamluaia L, Sarkar UK, Mishal P et al (2021) Assessment of the impact of fish seed stocking on fish yield in small reservoirs of Central India: towards sustainable management. Environ Sci Pollut Res 1-8

21. Lorenzen K (2000) Using Population Models to Assess Culture-based Fisheries: A Brief Review with an Application to the Analaysis of Stocking Experiments. In: ACIAR PROCEEDINGS. ACIAR; 1998, pp 257-265

22. Montanhini Neto R, Nocko HR, Ostrensky A (2017) Carrying capacity and potential environmental impact of fish farming in the cascade reservoirs of the Paranapanema River, Brazil. Aquac Res 48:3433-3449

23. Narayana J, Puttaiah ET, Basavaraja D (2008) Water quality characteristics of anjanapura reservoir near Shikaripur, District Shimoga, Karnataka. J Aqua Biol 23:59-63

24. Nguyen HS, Bui AT, Nguyen DQ et al (2005) Culture-based fisheries in small reservoirs in northern Vietnam: effect of stocking density and species combinations. Aquac Res 36:1037-1048

25. Nguyen SH, Bui AT, Le LT et al (2001) Aspects of the culture-based fisheries in small, farmermanaged reservoirs, based on three production cycles, in two provinces of northern Vietnam. Aquac Res 32:975-990

26. Oksanen J, Blanchet FG, Friendly M et al (2020) vegan: Community Ecology Package. R package version 2.5-6. 2019

27. Pawar SB, Shembekar VS (2012) Studies on the physico-chemical parameters of reservoir at Dhanegoan district Osmanabad (MS), India. J Exp Sci 3:51-54

28. Phan PD, De Silva SS (2000) The fishery of the Ea Kao reservoir, southern Vietnam: a fishery based on a combination of stock and recapture, and self-recruiting populations. Fish Manag Ecol 7:251264

29. Prabhahar C, Saleshrani K, Tharmaraj K, Kumar VM (2012) Seasonal variation in hydrological parameters of Krishnagiri Dam, Krishnagiri district, Tamil Nadu, India. Int J Pharm Biol Arch 3:134139

30. Pushpalatha KBC, Chandrasoma J (2010) Culture-based fisheries in minor perennial reservoirs in Sri Lanka: variability in production, stocked species and yield implications. J Appl Ichthyol 26:98-103

31. Pushpalatha KBC, Jayantha C, Fernando W, Sanjeewa KD (2017) Impacts and importance of introduction of culture-based fisheries in three medium sized perennial reservoirs in Sri Lanka. Asian Fish Sci 30:139-151

32. Rajashekhar AV, Lingaiah A, Rao S, Piska RS (2007) The studies on water quality parameters of a minor reservoir, Nadergul, Rangareddy district Andhra Pradesh. J Aqua Biol 22:118-122

33. Rao DSK, Karthikeyan M, Ramakrishna NR et al (2013) Culture-based fisheries in a large Indian reservoir-A case study at Krishnarajasagar (Cauvery river basin, Karnataka). In: Book of Abstracts, National Seminar on Emerging Trends in Indian Aquaculture. Department of Aquatic Biology and Fisheries, University of Kerala Trivandrum, p 28 
34. Sandhya KM, Lianthuamluaia L, Karnatak G et al (2019) Fish assemblage structure and spatial gradients of diversity in a large tropical reservoir, Panchet in the Ganges basin, India. Environ Sci Pollut Res 26:18804-18813

35. Sarkar UK, Bain MB (2007) Priority habitats for the conservation of large river fish in the Ganges river basin. Aquat Conserv Mar Freshw Ecosyst 17:349-359

36. Sarkar UK, Lianthuamluaia L, Panda D et al (2020) Evaluation and impact assessment of culturebased fisheries to enhance fish yield in small reservoirs in Odisha State, India. Fish Manag Ecol. https://doi.org/10.1111/fme.12429

37. Sarkar UK, Mishal P (2017) Status, Potentials and Prospects of Reservoir and Wetland Fisheries in India-An Overview

38. Sarkar UK, Sandhya KM, Mishal P et al (2018) Status, prospects, threats, and the way forward for sustainable management and enhancement of the tropical Indian reservoir fisheries: an overview. Rev Fish Sci Aquac 26:155-175

39. Sehgal KL (1994) State-of-art of endangered, vulnerable and rare coldwater fishes of India. Nat Conserv MUZAFFARNAGAR(INDIA) 127-135

40. Selvaraj C, Murugesan VK, Aravindakshan PK (1990) Impact of stocking of advanced fingerlings on the fish yield from Aliyar reservoir. Contrib to Fish InI Open Water Syst India Part I, IFSI, CIFRI, Barrackpore, India 109-114

41. Shrestha TK (1990) Rare fishes of Himalayan waters of Nepal. J Fish Biol 37:213-216

42. Shukla R, Bhat A (2018) Beta-diversity partitioning and drivers of variations in tropical fish community structure in central India. Aquat Sci 80:1-14

43. Singh TK (2014) Fish diversity in selected stretch of the River Mahanadi in Odisha and the livelihood of inhabiting fisher community. Int Res J Biol Sci 3:98-104

44. Sreenivasan A (1984) Influence of stocking on fish production in reservoirs in India. Fish Chimes 4:54-70

45. Sugnnan VV (1995) Reservoir fisheries of India. Daya Books

46. Sugunan VV (2011) Handbook of Fisheries and Aquaculture. Reserv Fish Trivedi, TP) Dir Knowl Manag Agric ICAR, New Delhi 238-274

47. Sugunan VV, Katiha PK (2004) Impact of stocking on yield in small reservoirs in Andhra Pradesh, India. Fish Manag Ecol 11:65-69

48. Verma PU, Chandawat DK, Solanki HA (2011) Seasonal variation in physico-chemical and phytoplankton analysis of Kankaria Lake. Life Sci Leafl 19:842-854

49. Vetriselvi A, Sivakumar K, Poonguzhali TV (2011) Seasonal variation of hydrographic parameters and distribution of nutrients in the Perumal lake. Tamil Nadu. Int J Res Environ Sci Technol 1:34-42

50. Wijenayake W, Jayasinghe UAD, Amarasinghe US et al (2005) Culture-based fisheries in nonperennial reservoirs in Sri Lanka: production and relative performance of stocked species. Fish Manag Ecol 12:249-258 
Figures

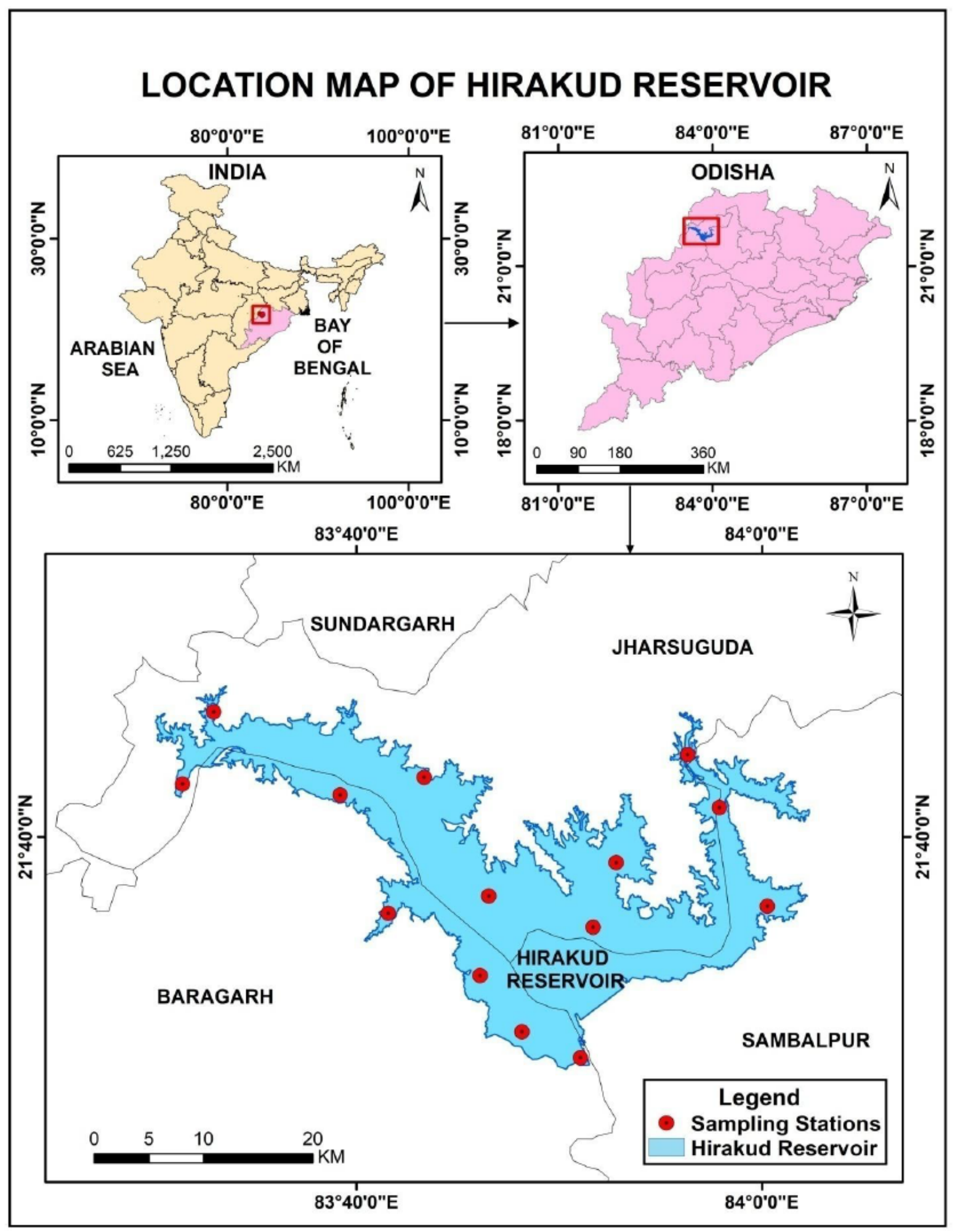

Figure 1 
Location of Hirakud reservoir with distribution of water spread area among three districts of Odisha, India.

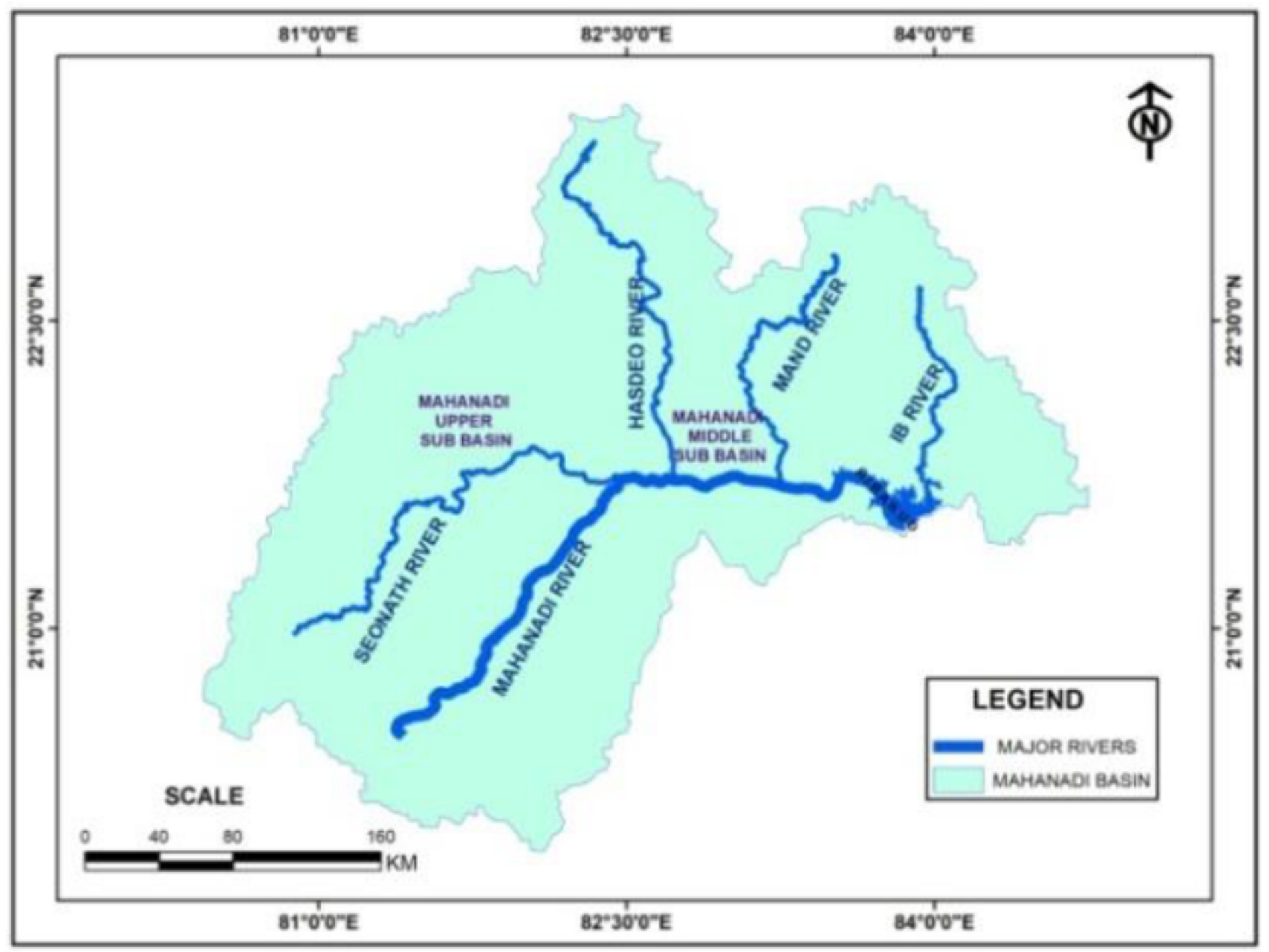

Figure 2

Map showing the Mahanadi river basin and Hirakud reservoir 


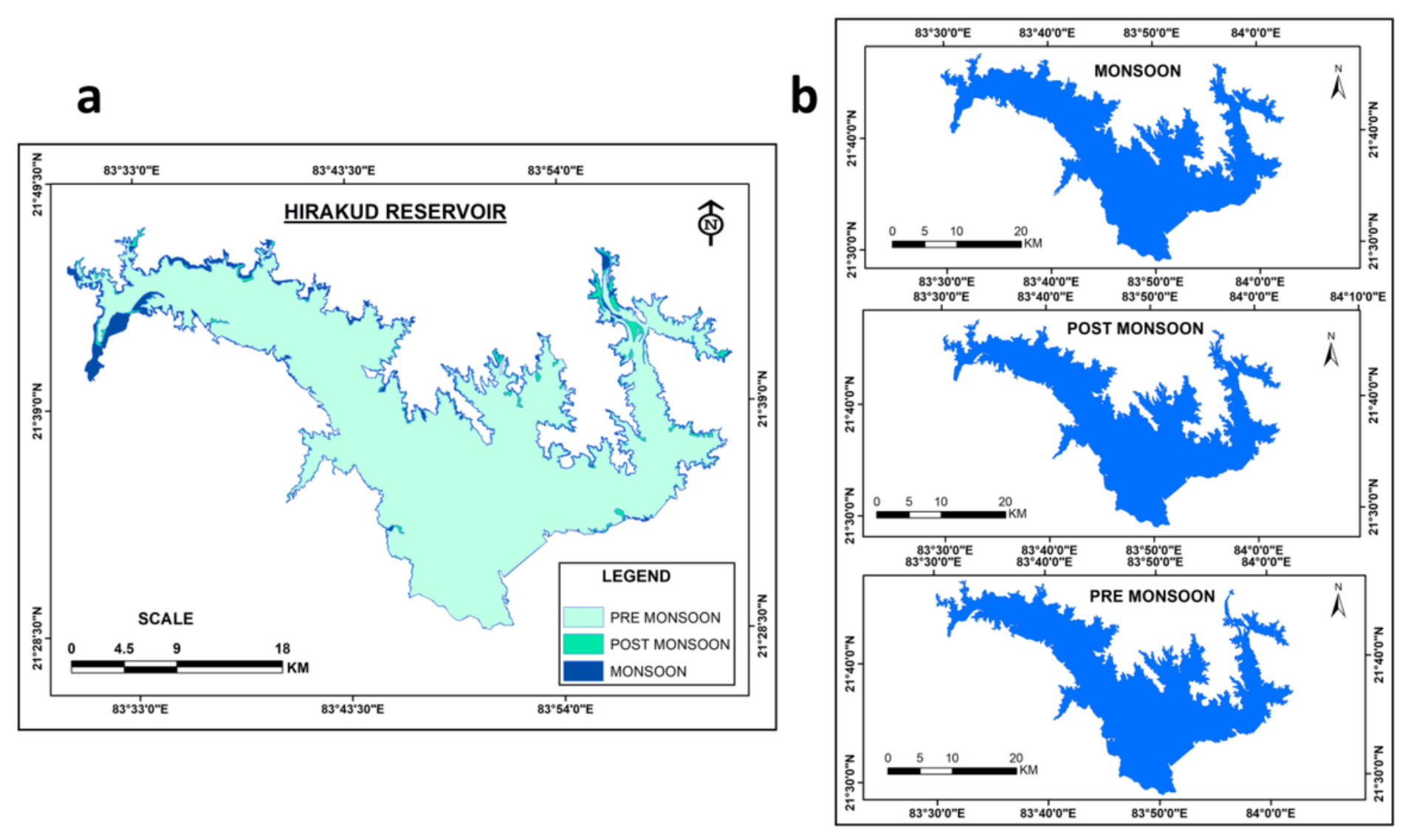

\section{Figure 3}

a\&b. Map in GIS platform showing the seasonal variations of water spread area in Hirakud reservoir 


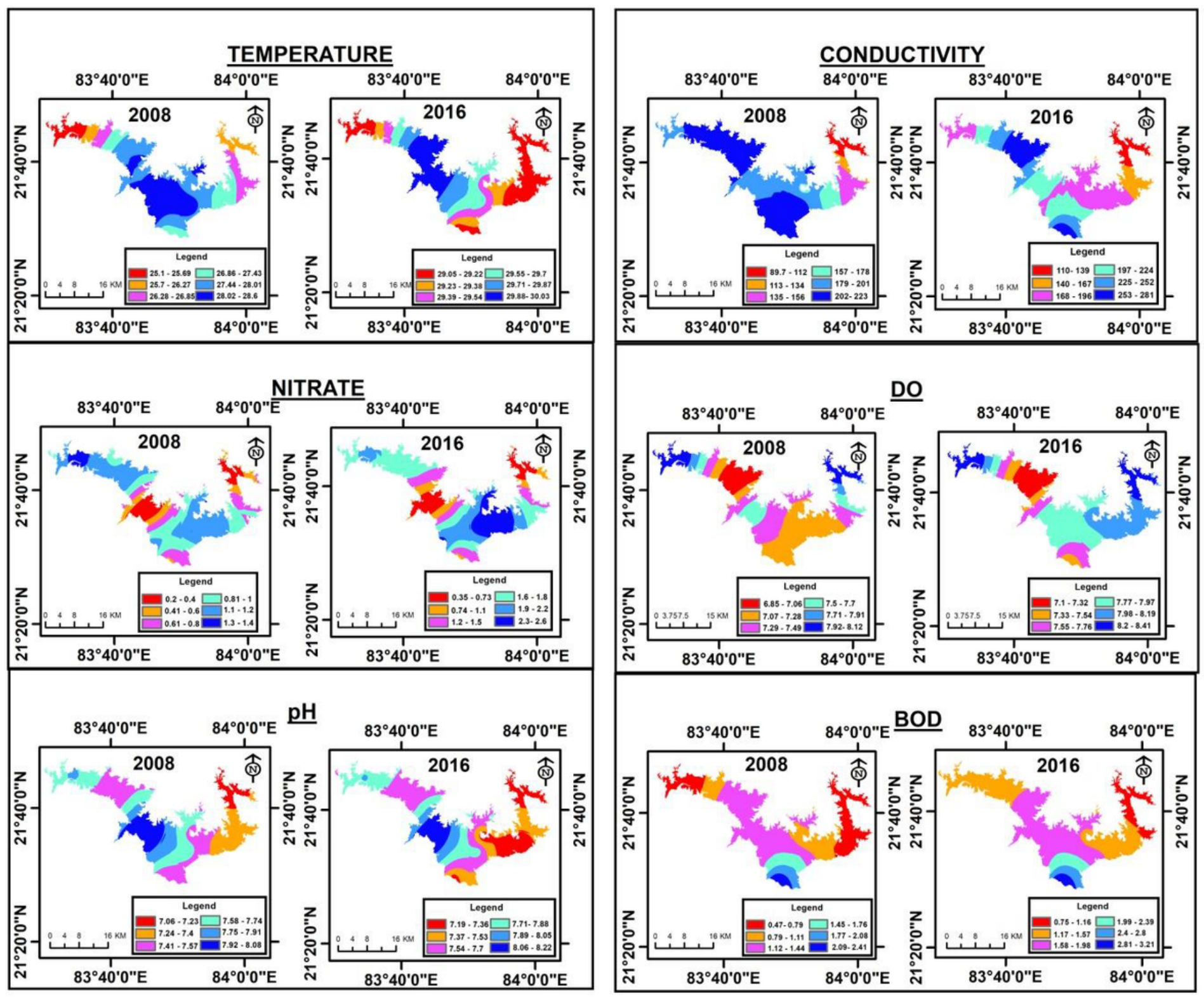

Figure 4

Spatio temporal variations of water quality parameter during 2008 and 2016 presented in GIS platform. 


\section{Average $\%$ of composition of different groups in total landing}

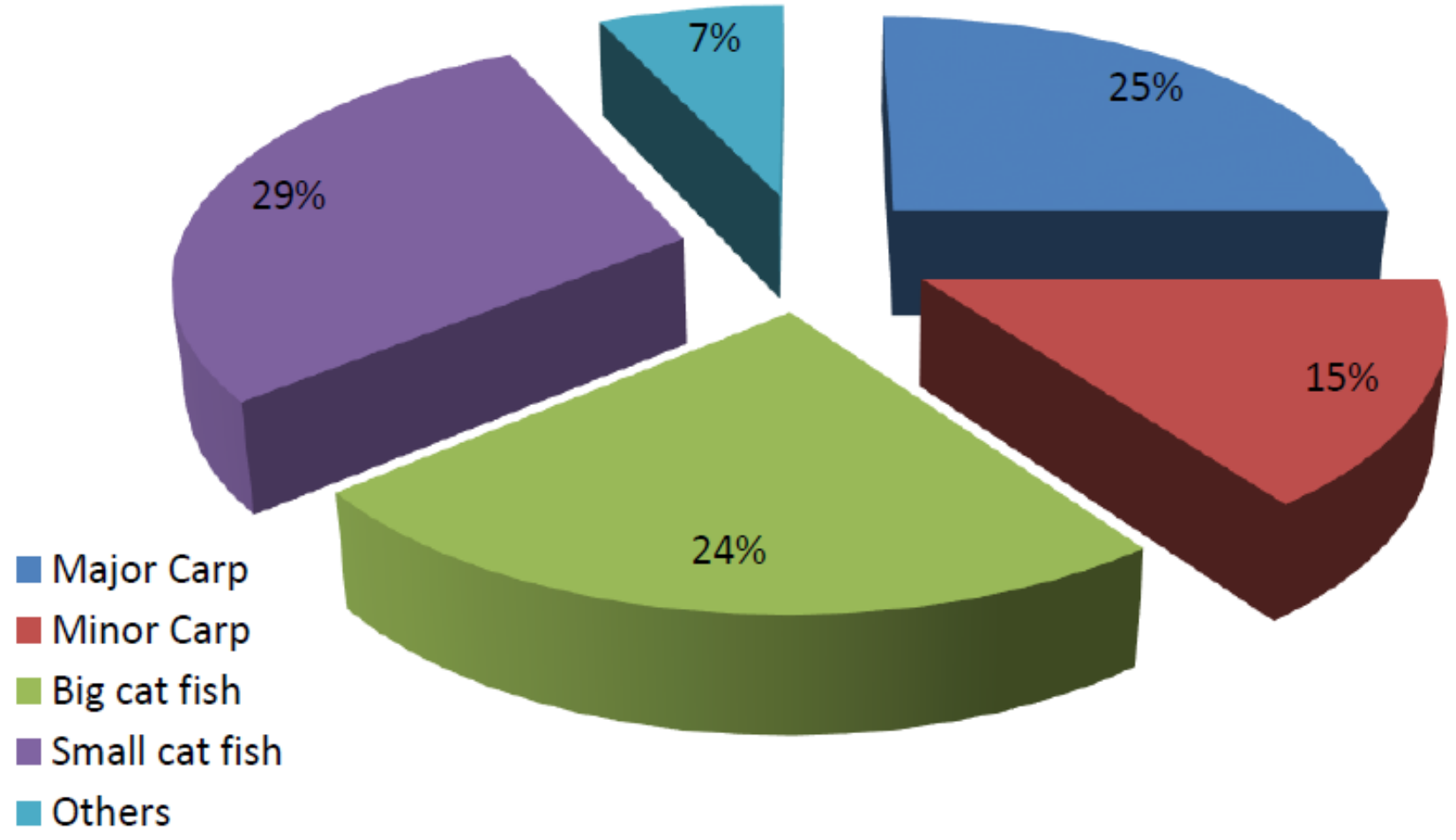

Figure 5

Composition of fish catch in Hirakud reservoir 
Forecasts from ARIMA(0,2,1)

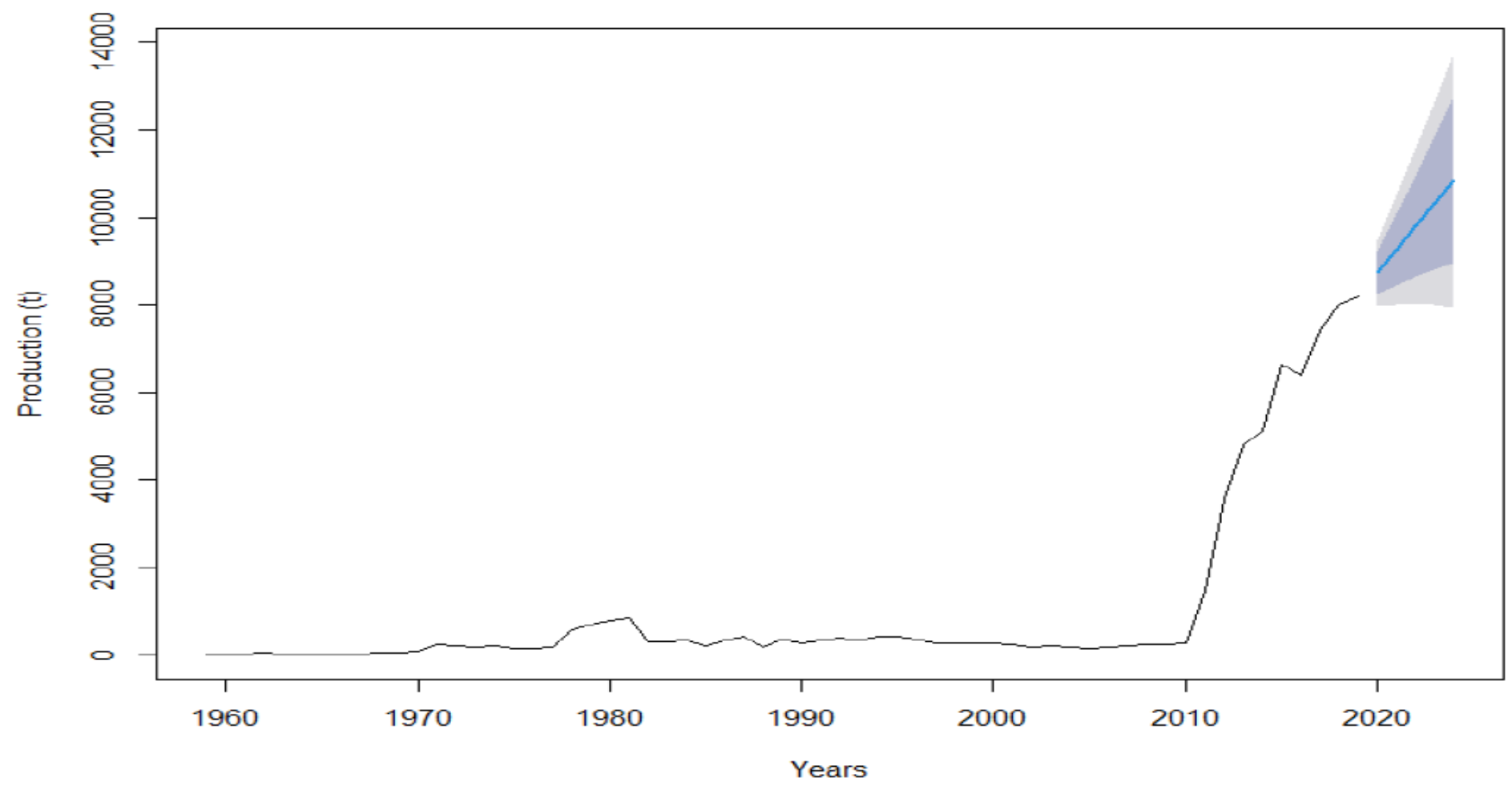

Figure 6

Trend and forecasting of fish production in Hirakud reservoir
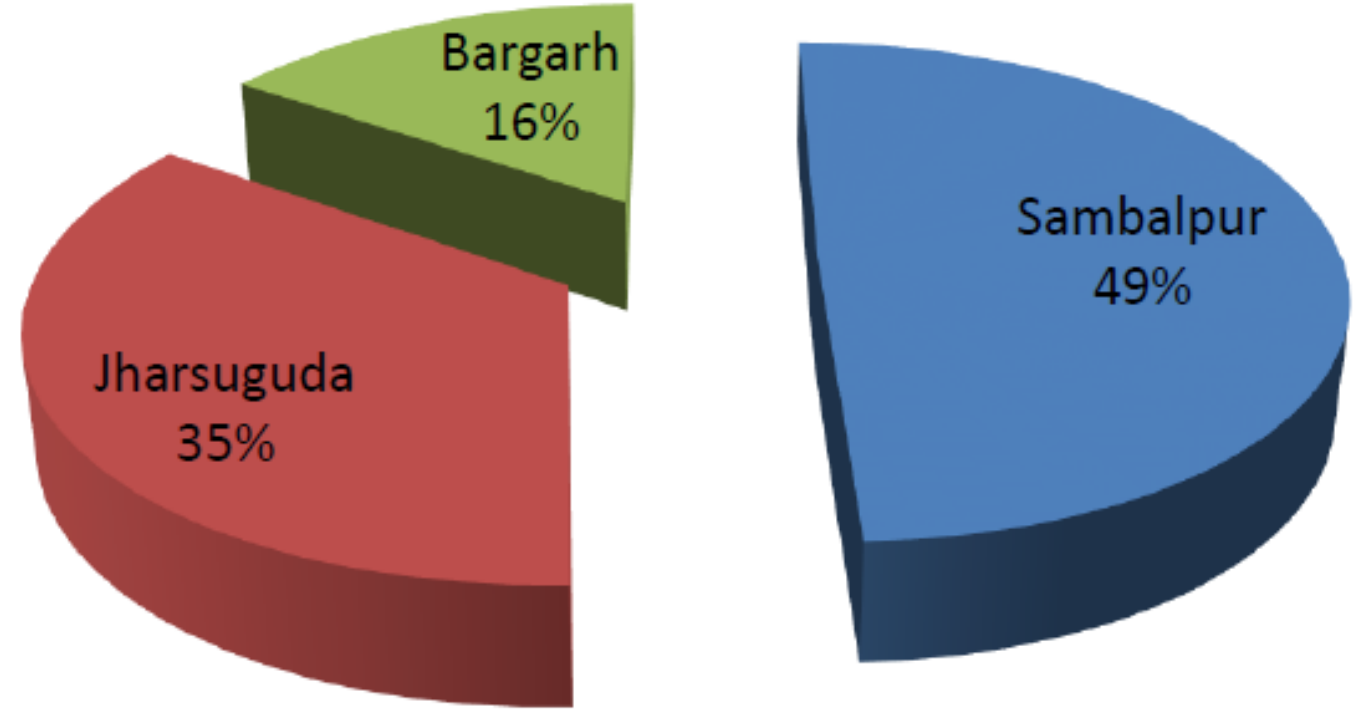

Figure 7 
Contribution of the three districts of Odisha for the fish production in Hirakud reservoir

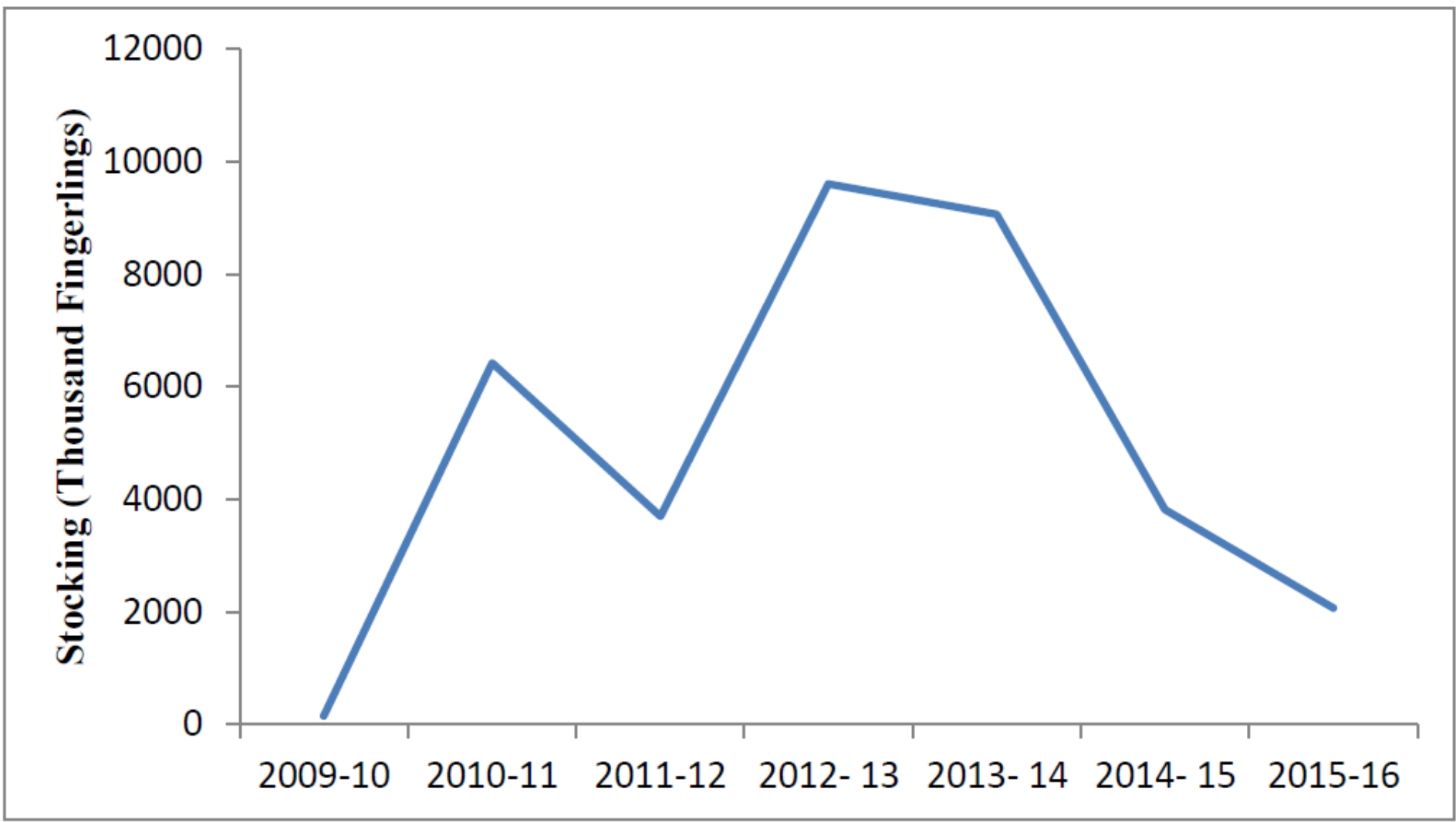

Figure 8

Stocking of fingerlings in Hirakudresrvoir 


\section{FIngerling stocking in different sectors of the resevoir from 2010 to 2016}
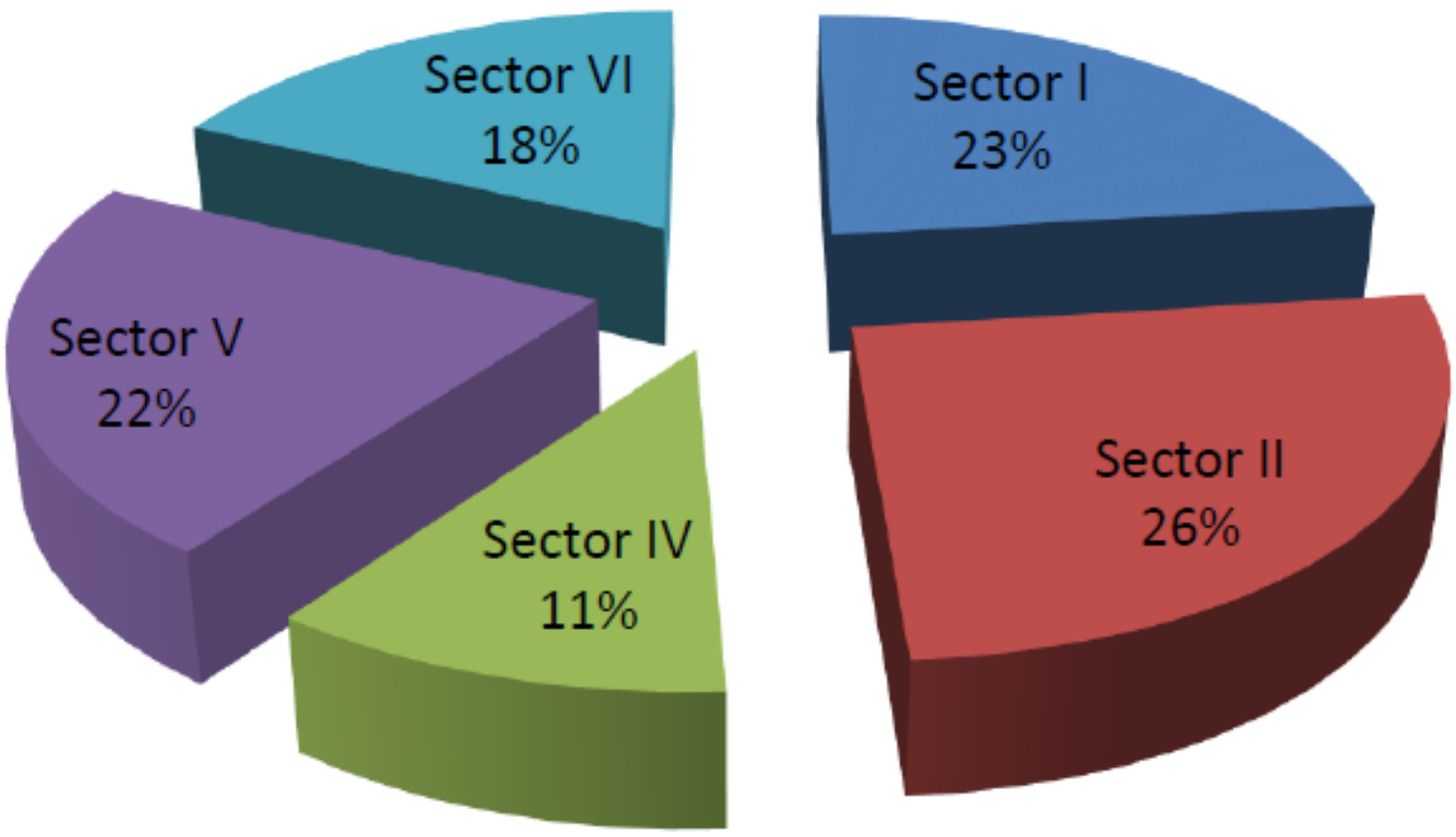

Figure 9

Fingerling stocking in different sectors of the reservoir from 2010 to 2016 


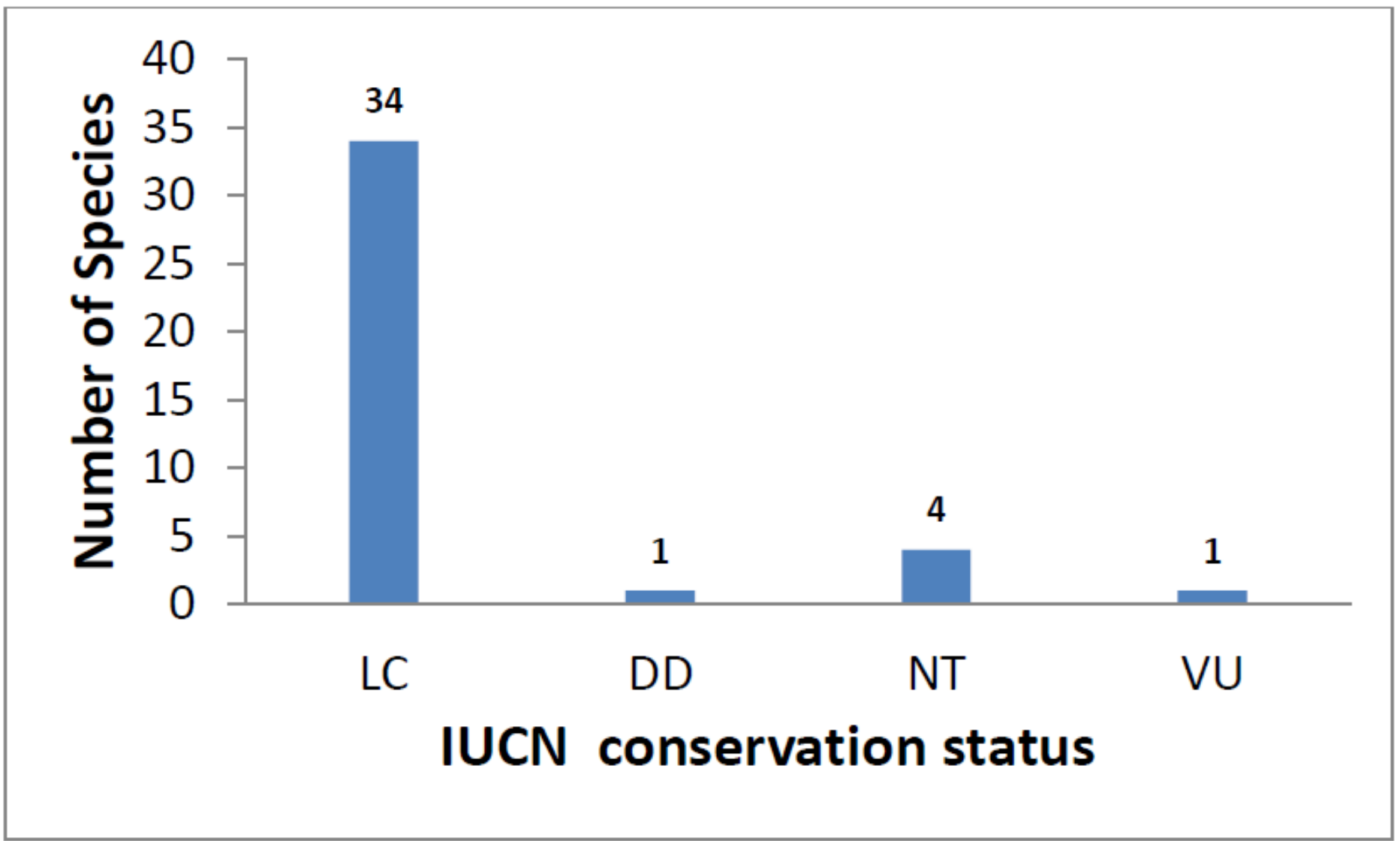

Figure 10

IUCN conservation status of the fish found in Hirakudreservoir 


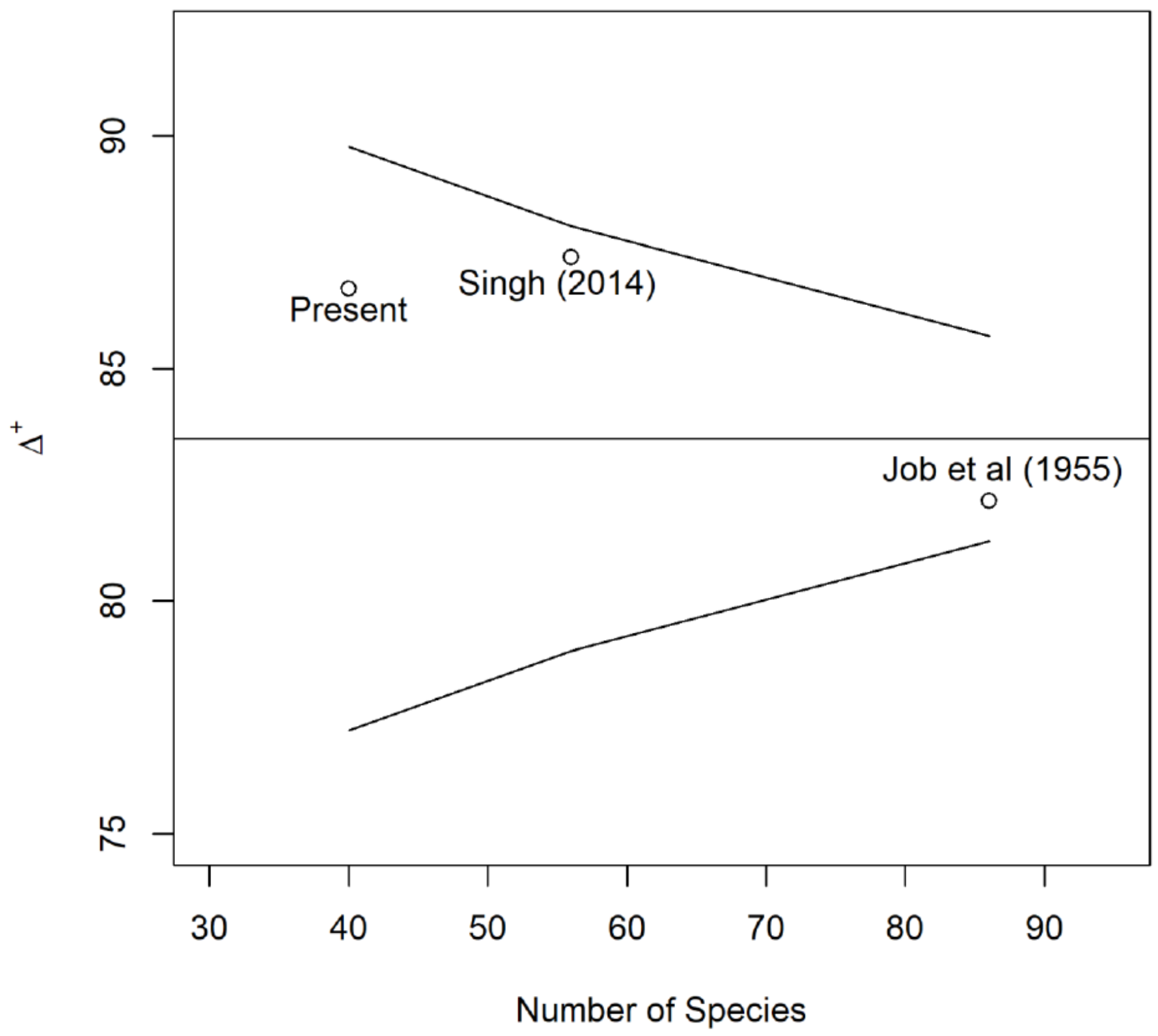

Figure 11

Temporal changes of taxonomic distinctness $\left(\Delta^{*}\right)$ of fish species in Hirakud reservoir 